\title{
Social Innovation and Entrepreneurship in Arunachal Pradesh: Opportunities and Challenges
}

Dr. Ravi Ranjan Kumar, ${ }^{\dagger}$ Dr. Kaushalendra Pratap Singh, ${ }^{{ }^{*}}$ and Ms. Leeyir Ete ${ }^{\ddagger}$

\section{Abstract}

Bio-geographically, Arunachal Pradesh is the wealthiest province of the entire Himalayas. The picturesque terra firma full of natural beauty and rich cultural opulence, in its entirety, falls under the eastern Himalayan landscape. This north eastern territory of the country was previously called "Terra Incognita" till the beginning of the 20th Century, and hitherto remains one of the least studied states in India today. The state's socio-economic development is currently in a transitional phase with variations across different districts. Considering the quality of social capital available, there is a dire need to emphasise proper resource flow and foster an understanding of the importance of the existent social capital. It may be noted that entrepreneurs are powerful instruments of development and economic change. So, panacea in the long term is the promotion of social innovation and entrepreneurship, which will give momentum to the State's developmental agenda and address the state's social issues. Indeed requires a motivating ecosystem which prioritises essential skills and innovation and adopts a fresh, sustainable view of resources and technology. Therefore, the present paper explores the prospects of social innovation and entrepreneurship in the state with particular reference to contemporary social concerns adopting a practice-based approach.

Keywords: Entrepreneurship; Social Concern; Social Innovation; SWOC Analysis; Arunachal Pradesh; India

\footnotetext{
${ }^{\dagger}$ Assistant Professor, Department of Social Work, Rajiv Gandhi (Central) University, Arunachal Pradesh, Email: ravi.ranjan@rgu.ac.in

*Corresponding Author, Assistant Professor, Department of Social Work, Rajiv Gandhi (Central) University, Arunachal Pradesh, Email: gaur.kpsingh@gmail.com

¥ Guest Assistant Professor, Department of Psychology, Rajiv Gandhi (Central) University, Arunachal Pradesh

(C) 2021 Kumar et al. This is an Open Access article distributed under the terms of the Creative Commons Attribution License (http://creativecommons.org/licenses/by/2.0), which permits unrestricted use, distribution, and reproduction in any medium, provided the original work is properly cited.
} 


\section{Introduction}

Arunachal Pradesh, literally meaning "the land of dawn-lit mountains"is biogeographically the richest province of the entire Himalayas (Lodrick, 2019). The picturesque terra firma full of natural beauty and rich cultural opulence, in its entirety, falls under the eastern Himalayan landscape. This north eastern territory formerly belonged to Assam. It was known as North East Frontier Agency (NEFA) from the British colonial era till it was constituted as an Indian Union Territory in 1972. Hereafter, it was recognised as an Indian state in 1987. Arunachal Pradesh was previously called "Terra Incognita" 1 till the beginning of the 20th Century (Deb, 2013)and today it stands as one of the least studied states in India (Sharma \& Chakraborty, 2016). The state's socioeconomic development is currently in a transitional phase with variations across different districts. Considering the quality of social capital available, it remains paramount to emphasise proper resource flow and understand the existent social capital's importance. Putnam treated social capital as a public good-the amount of participatory potential, civic orientation, and trust in others available to cities, states, or nations (Putnam 1993; 2000). Putnam's conceptualisation of social capital is elevated from a feature of individuals to a feature of large population aggregates. Social capital becomes a collective trait functioning at the aggregate level. Putnam made the argument that social capital is essentially the 'amount' of 'trust' available and is the main stock characterising the political culture of modern societies. For Putnam (1993, p. 35) social capital refers to 'features of social organisations, such as networks, norms and trust that facilitate action and cooperation for mutual benefit'. Putnam follows Coleman's belief that social capital is a quality that can be a facilitator of interpersonal cooperation. In Putnam's view, such a feature can be considered an aggregate trait to such a degree that it can become automatically comparable across cities, regions and even countries.

Arunachal Pradesh, the land of the rising Sun has its own unique topography and ethnicity with nine mighty Himalayan rivers flowing through the state. Despite its scenic natural beauty, the so-called "Terra Incognita" or No Man's Land (Nayak, 2011) had observed a disconnect from the outer world, owing to the geographical extremities. This inadvertently has contributed to the preservation of cultural heritage, as well as flora and fauna. Interestingly, in a single state as small as Arunachal Pradesh (in terms of demography barely 1.4 million population as per census, 2011), about 50 different languages are spoken. The tribal groups mainly speak TibetoBurman dialects belonging to the Sino-Tibetan family (Lodrick, 2019). The lingua franca, however being used in the region is Assamese, Hindi and English. The state currently has the country's lowest population density (17 per square kilometre, Census, 2011). It has more than 40 tribes and sub-tribes of distinct ethnicity which trace their lineage to Southeast Asia, Tibet and Mongolia. More than two-thirds of the whole population are officially recognised as Scheduled Tribes-a term used to designate indigenous people who do not come under the umbrella of the Indian social structure characterised by the varna system. Ancient India in the Vedic Period (c. 1500-1000 BCE) did not have social stratification based on socioeconomic indicators; rather, citizens were classified according to their Varna (loosely translated as Castes). 'Varna' defines the hereditary roots of a newborn, it indicates the colour, type, order or class of people. Four principal categories are defined: Brahmins (priests, gurus, etc.), Kshatriyas (warriors, kings, administrators, etc.), Vaishyas (agriculturalists, traders, etc., also called Vysyas), and Shudras (labourers). Each Varna propounds specific life principles to follow; newborns are required to follow the customs, rules, conduct, and beliefs fundamental to their respective Varnas (Ghurye,

\footnotetext{
${ }^{1}$ The present Arunachal Pradesh was a hidden land till it was explored by the British for the Outer World. Major General $\mathrm{H}$ Bower coined this hidden land as terra incognita during his Abor (Adi) Expedition of 1911 (Nayak, 2011).
} 
1969). The major tribes are the Nyishi, Adis, Galos, Apatanis, Mishmis, Sherdukpens, Akas, Monpas, and the Wanchos, Noctes and Tangsaswho mostly inhabit dispersed villages and isolated farmsteads. The tribes share similar rural lifestyles, and occupations like hunting and fishing and many people are subsistence farmers who gather forest products. Every tribe has its own unique socio-cultural and religious practices and follow endogamy (marrying within a specific group). Besides the Scheduled Tribes, the population also consists of immigrants from Bangladesh, Nagaland, Assam and other states (Lodrick, 2019). Papola (2008), in his study titled Employment Challenges and Strategies in India, highlights that employment continues to be one of the core challenges staring GDP growth of India. The situation becomes further grim with testing times like COVID 19 where economies world over are under an unprecedented slow down (World Bank, 2020).

In this backdrop, the article adopts a systematic structure in laying down its evidence and arguments beginning with this context setting deliberation as the introduction section. It goes on to specify the study's objectives and thereafter, describes the methodology subsequently to put forth the sources of data and analysis mechanism. Meaning and implications of social entrepreneurship appear immediately after the methodology section to clarify the core concepts and contextualise further discussion.SWOC (Strength, Weakness, Opportunity \& Challenges) analysis in the succeeding section provides an in-depth understanding of secondary data. Prospects of social innovation and entrepreneurship in Arunachal Pradesh provide an informed outlook towards emerging prospects and current scenario before concluding the article with a summary of each of the study's stated objectives.

As stated earlier, being one of the least studied states in India, Arunachal Pradesh is among the least known states in the country (Sharma \& Chakraborty, 2016). In this backdrop, the current study is an effort on the part of authors serving in the lone central university of the state since 2015 to share the state's specificities in the context of its social concerns and prospects of social entrepreneurship an overarching objective. In this regard, the current study is an attempt to build insights with regard to the following specific objectives:

- To draw the prospects of social innovation and entrepreneurship in the Arunachal Pradesh;

- To evolve the entrepreneurial strategies for addressing social concerns of the State.

\section{Methodology}

The article is based on secondary data sources. Referring to credible studies and sources, the study provides a thematic analysis of the combined data set delving into the state's prospects of entrepreneurship and social concerns. SWOC (Strength, Weakness, Opportunity \& Challenges) analysis provides an in-depth understanding of secondary sources. The ethical practice has been ensured by acknowledging all the sources of secondary data.

\section{Social Entrepreneurship: Meaning and Implications}

Unmet social needs in a society provide an opportunity for social entrepreneurship (Gandhi \& Raina, 2018). It takes a social entrepreneur to identify the currently prevailing bad equilibrium that exists due to unmet social needs and optimise it as an opportunity to create social value. In this section, this study identifies the opportunity for social entrepreneurship that is embedded in the social dynamics of Arunachal Pradesh. At the most basic level, social entrepreneurship can be understood as a business for a social cause, that is, altruistic entrepreneurship. It is an amalgamation of commerce and social issues that benefits those associated with the cause. Social entrepreneurs go beyond earning profits and equate success in being able to contribute to the world. The "earned income" model further elaborates this point as the money earned by the social entrepreneur supports a specific social cause be it providing soap to underprivileged areas to promote personal hygiene and cleanliness or 
selling whistles to advocate for peace (Besharov et al., 2019).

The customers are usually attracted to such businesses as they are allowed to be a part of the solution to a social problem. The characteristics shared by social entrepreneurs as highlighted by the Schwab Foundation (n.d.) for Social Entrepreneurship were: acquiring large scale social change, earning money with the focus and intent to create the required social or ecological change, using innovation and creativity when trying to solve a social problem emphasising on feedback to adapt to changes and refine strategies.

According to a report by Forbes (Fox, 2016), 94\% of the youth admitted to utilising one's skills for a social cause. Hence, for the youngsters today, making an impactful social change in the world is as vital as earning money. This highlights a new social enterprise approach today, wherein a combination of capitalism with altruistic goals is adopted, to achieve success. These self-funded businesses work on national and international platforms and take on humanity-oriented goals to tackle social issues like hunger, education and climate change by partnering with Governmental or philanthropic bodies, funding specific programs or following a one-on-one donation model.

According to the Ministry of Skill Development and Entrepreneurship (MSDE), Government of India (2015), more than half of the Indian population are below the age of 25 years, and about two-thirds belong to the working-age category (15-59 years). However, despite the massive potential for the country's labour supply, there persists a paucity of skilled workers. A workforce armoured with strong employable knowledge and skill could largely shape and contribute to the national economic growth and play a defining role in initiatives such as Smart City, Digital India, and Startup India (PwC, 2014). Currently, there are 52 schemes in the Indian Himalayan Region (IHR) from 14

${ }^{2} \mathrm{IMI}$ and Food and Agriculture Organisation (FAO) completed a project together to enhance its outreach capability across the Indian Himalayan Region through establishment of Sustainable Development Forums different Central Government Ministries and Departments in entrepreneurship aimed at the inception of self-employment to spawn "necessity" and "opportunity" entrepreneurs. According to Integrated Market Initiative (IMI) and Food and Agriculture Organization (FAO), ${ }^{2}$ these policies focus on providing training and creating an empowering environment through mentorship via incubators and accelerators and improving financial access to the necessary risk capital (IMI \& FAO, 2019).

It is evident through these studies that social innovation and entrepreneurship is significant for a socio-economically emerging state like Arunachal Pradesh. It is further essential to inculcate an understanding of prevailing circumstances in the state with SWOC analysis (Strength, Weakness, Opportunity and Challenges) to optimise the same taking stock of the ground realities both in terms of constraints as well as strengths.

\section{Arunachal Pradesh: Problems, Prospects and SWOC Analysis}

According to the 2011 Census report, Arunachal Pradesh, with an area of $83,743 \mathrm{sq} \mathrm{km}$, is one of the country's largest frontiers states. It comprises of 3,863 villages and a total population of 13,82,611 (1.38 million) persons (713912 (0.71 mn) males and 669815 (0.67 mn) females). According to the same report, Arunachal Pradesh has a literacy rate of $65.38 \%$. Out of 766,005 (0.76 mn) literates, 439,868 (0.44 mn) are males, and $326,137(0.32 \mathrm{mn})$ are females. The numbers further differ in rural and urban regions. The urban region with an average of 82.93\% literates has a higher male literacy rate at $88.45 \%$ while the female literacy rate stands at $67.14 \%$. The average rural literacy rate is $59.94 \%$ with male literacy at $67.44 \%$ and female literacy at $49.14 \%$. Of the total population of Arunachal Pradesh, a major chunk lives in the villages. About 1,066,358 (1.66 mn) constituting $77.06 \%$ of the total population live in the villages while 317,369 ( $0.31 \mathrm{mn}$ ) that is, only $22.94 \%$ live

under"Strengthening Institutional Capacities for Sustainable Mountain Development in the Indian Himalayan Region". 
in urban regions. The rural population has 546,011 (0.54 mn) and 520,347 (0.52 mn) males and females, respectively. The rural sex ratio is 953 females per 1000 males. In urban regions, the male population is $167,901(0.16 \mathrm{mn})$ and 149,468 (0.14 mn) are females. The urban population has increased by $22.94 \%$ in the last ten years. Sex ratio in urban regions is 890 per 1000 males. As per Unique Identification Aadhar India, as updated in December 2019, by the end of the year 2019, the projected population was estimated to be around 1,548,776 (1.5 mn).

According to the 2011 Census report, 3.64 Lakh $(0.36 \mathrm{mn})$ persons of the state fall in the age group of 15-29 years, mostly engaged in education or looking for employment. According to the reports of a Skill-gap-study in the year, 2011 carried out by the Investment Information and Credit Rating Agency (ICRA) Management Consulting Services (IMaCS) in the North East Region, Arunachal Pradesh is estimated to have a human power supply of $0.75 \mathrm{mn}$ between the year 2011- 2021

Therefore, the primary quest would be to channel this vital, youthful energy in the most productive direction. Moreover, since the land has mostly been under the Central Government's focus from a perspective of national integration and economic development, the areas of "Entrepreneurship Development" are yet to gain its due importance.

A look at the history of industrial development in Arunachal Pradesh shows that the first initiative-Policy of Craft Promotion - began via the Department of Cottage Industries Development in 1952. In the words of Gunnar Myrdal (Myrdal, 1968, p.1290),"[c]rafts and small-scale enterprises have deep and wellestablished roots in South Asia's indigenous economic development (Asian Drama) and true for the ethnically rich crafts of the state too". The first tribal hallmark of the North East Frontier Agency (NEFA) emerged due to a 1947 photograph captured by Verrier Elwin, of a Konyak (a Naga tribe) woman weaving, which was displayed on the Republic Day of the country in 1955(Elwin,1959). A possible explanation of the delayed development in the area can be attributed to the inadequate focus and importance on the ethnic arts and crafts of the state. To effectively bring about maximum progress and all-round growth of the villages, it is crucial that the issue of migration be addressed, which in essence, is an indicator of rural poverty and labour division and distribution according to the demands of the market. According to a scholar Gupta, Dipankar (2007) "the Indian villages have started disappearing" which highlights the ongoing trend of rapid migration from rural to urban areas across India, which is rapidly infecting the youth's minds. Hence, in line with the Keller's conclusion of the rural-migration issue (Keller, 2000), there is a dire need to boost and reinvigorate the rural areas to avoid the urban towns' pressure, owing to a lack of facilities and services.

Arunachal Pradesh's state has many schools and educational institutions, including Arunachal University founded as a state government university in 1984, which was later recognised by India's Parliament as a Central University in 2007, renaming it as Rajiv Gandhi University. It also consists of various specialised institutes for the fields of forestry, education, engineering, agriculture and industry (Rajiv Gandhi University, 2020). However, despite the establishment of various schools in the primary, secondary, and higher secondary levels, the state continues to have one of the country's lowest literacy rates.

The primary health concerns of the state include Tuberculosis, Malaria and Dengue fever. Tuberculosis has been recognised as one of the region's primary health issues, and many hospital facilities have been identified as Tuberculosis treatment centres. The state government has taken part in various national programs to control vector-borne diseases (like Japanese Encephalitis, Malaria, Dengue fever) and leprosy. Table 1 (below) attempts to provide a simplified understanding of the contemporary socio-economic constraints and prospects in Arunachal Pradesh: 


\begin{tabular}{|c|c|c|c|}
\hline & Indicator & $\begin{array}{l}\text { Weakness and } \\
\text { Challenge }\end{array}$ & Strength \&Opportunity \\
\hline 1 & $\begin{array}{l}\text { Physical } \\
\text { Infrastructure }\end{array}$ & $\begin{array}{l}\text { Difficult Terrain } \\
\text { Connectivity Issues }\end{array}$ & $\begin{array}{l}\text { Since the state has hardly two railway stations } \\
\text { that too in capital city only and no airport with } \\
\text { regular flights services, there is ample scope } \\
\text { for development in last-mile connectivity, } \\
\text { road, transport, communication and electricity. }\end{array}$ \\
\hline 2 & $\begin{array}{l}\text { Social } \\
\text { Infrastructure }\end{array}$ & $\begin{array}{l}\text { Human Resource } \\
\text { Development } \\
\text { Equitable } \\
\text { Distribution }\end{array}$ & $\begin{array}{l}\text { Availability, Accessibility and Affordability of } \\
\text { Quality Health and Education Services for all }\end{array}$ \\
\hline 3 & $\begin{array}{l}\text { Vulnerable } \\
\text { Groups }\end{array}$ & $\begin{array}{l}\text { One of the leading } \\
\text { states in infant and } \\
\text { maternal mortality }\end{array}$ & $\begin{array}{l}\text { Low Population Burden } \\
\text { Awareness and Emergency Services } \\
\text { Elderly and Disability Care }\end{array}$ \\
\hline 4 & $\begin{array}{l}\text { Natural } \\
\text { Resource } \\
\text { Management }\end{array}$ & $\begin{array}{l}\text { Human-Animal } \\
\text { Conflict on an all- } \\
\text { time rise } \\
\text { Depletion of natural } \\
\text { biodiversity }\end{array}$ & $\begin{array}{l}\text { Scope for investment in natural resource } \\
\text { management } \\
\text { Eco-Tourism }\end{array}$ \\
\hline 5 & $\begin{array}{l}\text { Youth } \\
\text { Development }\end{array}$ & $\begin{array}{l}\text { Rising } \\
\text { Unemployment } \\
\text { Substance and Drug } \\
\text { Dependence } \\
\text { Road Safety } \\
\text { Depression and } \\
\text { Suicide }\end{array}$ & $\begin{array}{l}\text { Educated Youth } \\
\text { Employability concerns } \\
\text { Need for De Addiction } \\
\text { Mental Health Services } \\
\text { Dearth of Trained Professionals }\end{array}$ \\
\hline 6 & $\begin{array}{l}\text { Market linkage } \\
\text { and Economic } \\
\text { Growth }\end{array}$ & $\begin{array}{l}\text { Lack of agro- } \\
\text { processing } \\
\text { industries } \\
\text { Last-mile } \\
\text { connectivity } \\
\text { literacy and } \\
\text { awareness }\end{array}$ & $\begin{array}{l}\text { Biodiversity Hotspot } \\
\text { Organic Produce } \\
\text { Handicrafts } \\
\text { Cultural Products }\end{array}$ \\
\hline 7 & $\begin{array}{l}\text { Health and Well } \\
\text { Being }\end{array}$ & $\begin{array}{l}\text { High Prevalence of } \\
\text { HIV, Cancer and } \\
\text { Tuberculosis cases } \\
\text { Drinking water } \\
\text { Solid Waste } \\
\text { Management }\end{array}$ & $\begin{array}{l}\text { Skilled Human Resource, and } \\
\text { Early Detection and Diagnostics }\end{array}$ \\
\hline
\end{tabular}

As a biodiversity hotspot recognised by the United Nations, Arunachal Pradesh is blessed with an abundance of natural resources and ethnic tribal knowledge about the natural ecosystem. This stands in direct contrast with the prevailing backward status of its villages wherein issues like poverty, low literacy rates and poor health still characterise the prevalent socioeconomic fabric. Effective solutions to these problems can be brought about by inspired citizens who challenge the status quo with their entrepreneurial ardour and innovative 
dispositions and generate ideas based on the region's core strengths and assets.

\section{Prospects of Social Innovation Entrepreneurship in Arunachal Pradesh}

and

\section{Eco-Tourism and Avi-Tourism: Prospects for Sustainable Mountain Tourism}

Arunachal Pradesh is a picturesque home to unexplored valleys, prominent monasteries and serene lakes making it a hotspot for tourism and vacations. It consists of the rich biodiversity of flora and fauna within unique habitats of grand mountains, glaciers, gentle meadows and dense sub-tropical forests and houses more than 500 endangered bird species. The state shares international boundaries with many countries like China, Myanmar and Bhutan and is also well known as the "Orchid State of India" or the "Paradise of the Botanists". The region is renowned for its breathtaking scenic natural beauty and warm, crafty people who give the foremost importance to one's cultural roots and traditions. Hence, there is a massive prospect for skill development and entrepreneurship associated with tourism in areas like wildlife, adventure, culture $\&$ heritage and rural sectors, with special reference to ethnic crafts and religious traditions.

\section{Natural Resource Potential}

It is a well-known fact that Arunachal Pradesh has a significant, untapped reservoir for massive energy generation. Its primary resources for energy production are rivers, hydrocarbons like coals and petroleum and minerals like dolomite, limestone, marble and quartzite (Shira, \& Devonshire-Ellis, 2012). The state mostly draws its power from hydroelectric sources and aims to augment hydroelectric and solar power production in the 21st Century, for example, the Lower Subansiri Hydroelectric Power Project (LSHEP) will be the single largest hydroelectric plant in India when completed. The state's geography is a complex hill system with an altitudinal variation ranging from $50 \mathrm{~m}$ in the foothills that gradually ascends to peaks that are as high as $7000 \mathrm{~m}$ and cuts through numerous rivers and rivulets. Except for the south-eastern areas in the Patkai Hills region, most of the territory falls under the Eastern Himalayas (Lodrick, 2019).

The state receives large amounts of rain, spread over 8 to 9 months every year, starting from spring to autumn. The higher elevations receive a lesser amount of rainfall. This variation in climate and topography has favoured the growth of massive forests where a delicate, graceful and symbiotic relationship exists between the tribes, the forest and the wildlife. Nature has indeed been exceptionally kind to Arunachal Pradesh. The state has five different types of forests and the sixth type of secondary forests - tropical forests, sub-tropical forests, pine forests, temperate forests and alpine forests. These forests harbour significant biodiversity with over 5000 plant species 86 land mammals, 500 birds and an equally diverse insect and reptilian life. Such unparalleled diversity of life can be credited to the region's unique location, falling at the intersection of three different bio-geographic hotspots; the Paleo arctic, Eastern Himalaya, and Indo-Burma regions (Myers et al., 2000).

\section{Handicrafts and Manufacturing}

Regarding manufacturing, Arunachal Pradesh mainly consists of medium and small-scale industries like rice and vegetable-oil milling, fruit processing, manufacture of forest goods and steel fabrication (Lodrick, 2019). The sectors of the handicrafts industry include weaving, basketry and carpets. Furthermore, sericulture is also one of the sectors of growing prominence and the state today deals in the production of many silk yarns. There have been significant efforts to expand marketing and industries at commercial towns like Itanagar, Naharlagun, Deomali and Pasighat through various governmental policies aimed at economic development.

\section{Agri-Entrepreneurship: Organic Farming, Arunachal Pradesh may become a model}

The Indian Green Revolution initiated synthetic fertilisers in the country's agricultural scenario in the early 1960s to meet the high demands of food production. Eliazer Nelson et al.(2019) in their study titled, The Impact of the Green revolution on Indigenous Crops of India highlight 
that with surplus production came severe threats to physical health and well-being, due to which organic farming was re-adopted in the late 90s, and the country launched the National Project on Organic Farming in 2004. Today, there is a high rise in the land and revenue under organic cultivation. According to a joint report of 2016 by Asso-cham and TechSci Research, the estimates for the organic food market in India is over US\$0.50 billion. The consumers of organic products today are not just interested in following a trend but have become keenly concerned with the medicinal and health benefits related to such endeavours (Deb, 2018).

Against this backdrop, organic farming potential in Arunachal Pradesh can be fulfilled via a unique combination of traditional skills with modern technology. There could be a special emphasis on mountain and forest products, spices, offseason vegetables and plants producing aroma, medicines, handlooms and handicrafts. Organic farming has always been the healthiest alternative to cultivation and agriculture, and felicitous entrepreneurship in this sector can help bear fruitful outcomes for the state and the country on the whole.

\section{Ecosystem Services-Based Employment: Bamboo Based Activities (Green Gold Industry)}

Another area of great potential for entrepreneurial interest could be employment in the bamboo-based sector. Arunachal Pradesh is naturally blessed with varieties of Green Gold (that is, Bamboo). The Indian Express(Sareen R., 2017), published a report on how bamboo cycles could soon be used on tracks. These eco-friendly, sturdy and easy to ride bamboo cycles that only weigh 2 kilograms are manufactured by ten agricultural families, involved in a bamboo plantation near Pune and are a better alternative to its plastic counterparts. The state can adopt such examples to promote the use of various eco-friendly products and ensure efficient use of the abundance of Green Gold present in the region. Therefore, afforestation, strategic use of wood for construction and other products and an in-depth assessment of the ecosystem services could yield golden opportunities to fuse state-of-the-art technological innovations with traditional skills and knowledge to develop an efficient entrepreneurial landscape.

\section{Folk Culture}

'Resilience' and 'Sustainability have been the hallmark of folk culture in Arunachal Pradesh. The tribal population has beautiful and culturally distinct garments and headdresses, so the art of weaving with different textile designs and patterns for each tribal group has always been of significant interest amongst the nativesanother culturally rich art of the tribal folk, integral to the community life is the various dances. Nyokum, Losar, Mopin, and Solung are major tribal festivals (Kamei, 2019). Protection and promotion of culture-specific practices may be a potential domain for social entrepreneurs in the state to prosper and suggest innovative mechanisms syncing them with technological advancements, social change and globalisation.

\section{Information Technology Enabled Services (ITES) and Digital Health}

The state also holds massive potential for ITES like banking, e-commerce, insurance, healthcare, mobile applications and services, telecommunication and financial services which can be accomplished by the generation of skilled employment opportunities for the local youth.

\section{Skilled Construction Sector}

Employees in the skilled construction sector are highly required for developmental schemes in sectors like urban and renewal projects pertaining to projects like public transportation, smart cities in addition to major infrastructures - transport, power stations, hydropower, and real estate. The youthful, energetic potential of the state in this department can also be directed in this field.

\section{Rural Technology and Marketing}

The Polish proverb, "If the farmer is poor then so is the whole country" rightly relates to the state of the country, as a quarter of the world's poor, almost 300 million, live in India (Varma \& Ravi, 2017). Even though the IT sector's employment rates come close to only about a million, it makes up almost 4 per cent of the GDP (Singh, 2018). Technologies in the rural sector like animal 
vaccination, development of watershed, the innovation of agricultural tools, drip irrigation and food preservation can positively contribute to the developmental growth of the whole nation by transferring better and more frequent services to the villages, eradicating inequalities and improving the overall quality of life for each citizen, especially the marginalised sections of the society. A good example is the STARS (Skill Training for Advancement in Rural Societies) Forum which aims at the promotion of essential skills in rural and tribal sectors, and provision of a platform for discussions pertaining to problemsolving and sharing of innovative practices and ideas(Skills Training for Advancement in Rural Societies,2020). Perhaps approaches such as these with a particular emphasis on promoting exposure and networking with such established organisations is what Arunachal Pradesh needs to bear fruitful outcomes to its developmental endeavours.

\section{Conclusion}

The current study has been an effort on the part of authors to reflect and deliberate on the state's specificities in the context of its social concerns and prospects of social entrepreneurship as an overarching objective. It has emerged through the literature available analysed in the backdrop of authors' empirical understanding based on their half a decade of teaching and learning on social issues in the region that the state of Arunachal Pradesh has fundamental concerns of social as well as physical infrastructure. However, the quality and variety of social capital and abundance of other natural resources of the place as duly acknowledged by a few recent and scholarly studies like that of Sharma \& Chakraborty (2016) and Gandhi \& Raina (2018) makes it one of the most potent locations for the growth and development of Social Innovations and Entrepreneurship in the near future.

Also, there is a dire need to recognise and ensure that young minds learn and thrive in the right atmosphere often elaborated in academic jargons as enabling environment to be able to optimise their potential and be successful. One can agree to the fact that the world today is filled with unpredictable and unfathomable challenges and that life is being lived on the fast lane. So, there persists an urgent need for the youth to be employed and engaged pro-actively for efficiently responding to these uncertainties and challenges which have been further aggravated globally with the multi-dimensional detrimental effects of COVID 19 pandemic of which Arunachal Pradesh has been no exception.

In these trying times, an efficient and potential answer to this issue could be entrepreneurship. For a country's sound economic and technical growth, both skill development and generation of job opportunities need to be focused simultaneously. Therefore, there is a pressing need for the growth, development, and promotion of good entrepreneurial quality for youth aspirations, as entrepreneurship is slowly becoming the backbone of India's economy.

It may be concluded that entrepreneurs are powerful instruments of development and economic change. In the long term, panacea is entrepreneurship in potential areas like agriculture, tourism, rural sector and womenfocused departments. Such promotion of social innovation and entrepreneurship will give momentum to the State's developmental agenda and address the social issues of the state. A motivating ecosystem which prioritises essential skills and innovation, and adopts a fresh, sustainable view of resources and technology is necessary to groom the youth with the relevant skills. If entrepreneurship is the "way forward" for the state, towards a sustainable, thriving future, impartial social order along with the dignity of labour; once a prized asset of the tribals, need to be restored to encapsulate the vision into a reality. The World Travel and Tourism Competitiveness Report 2019 (World Economic Forum, 2019) states that India can become the best tourist destination globally, with a rising yearly demand of $10 \%$. Perhaps a loud echo, towards a similar direction is what the Dawn Lit State of Arunachal Pradesh needs as a silver lining.

\section{References}

Assocham \& TechSci Research. (2016, November). Indian FMCG Market, 2020. https://www.techsciresearch.com/admin/gall_c 
ontent/2016/11/2016_11\$̦thumbimg102_Nov_ 2016_004628313.pdf

Besharov, M. (2019). How to create a successful earned-income model: Integrating revenue generation without losing sight of mission.

Béteille, André (1965). Caste, class, and power: Changing patterns of stratification in a Tanjore village. University of California.

Census of India (2011). Primary census abstracts, registrar general of India, Ministry of Home Affairs, Government of India.

https://www.censusindia.gov.in/2011-provresults/data_files/arunachal/Prov.\%20Popul\%2 0Total\%20-I.pdf

Census (2011).

http://www.census2011.co.in/census/state/aru nachal+pradesh.html

Deb, S. (2013). Study of Monpa and other tribes of Tawang and West Kameng Districts, Arunachal Pradesh. Journal of Global Economy, Research Centre for Social Sciences, Mumbai, India, 9(4), 263-274.

Deb, S. (2018). North East Region and Arunachal Pradesh (India): Looking beyond \& within in Pursuit to Promote Entrepreneurship. Advances in Economics and Business, 6(3),190-200, DOI: 10.13189/aeb.2018.060305

Eliazer Nelson, A.R.L., Ravichandran, K. \& Antony, U. (2019). The impact of the Green Revolution on indigenous crops of India. Journal of Ethnic Foods, 6 (8).

https://doi.org/10.1186/s42779-019-0011-9

Elwin, V. (1959). A philosophy for NEFA.

Shillong. NEFA.

Fox, M. (2016). 5 reasons why social entrepreneurship is the new model.

Forbes.com.https://www.forbes.com/sites/mei meifox/2016/08/08/5-reasons-why-socialentrepreneurship-is-the-new-businessmodel/\#6da8c744ca7e

Gandhi, Tanvi \& Raina, Rishav (2018). Social entrepreneurship: the need, relevance, facets and constraints. Journal of Global Entrepreneurship Research. 8(9). https://doi.org/10.1186/s40497-018-0094-6
Ghurye, G. S. (1969). Caste and race in India. Popular Prakashan.

Government of India (2015). National Policy for Skill Development and Entrepreneurship, 2015, Ministry of Skill Development \& Entrepreneurship, New Delhi.

Gupta, D. (2007). The vanishing village: Policy implications for India in the era of

Globalization.

https://www.wilsoncenter.org/.../thevanishing-village.

Integrated Mountain Initiative (IMI) \& Food and Agriculture Organisation (FAO) (2019). State of the Himalayan Farmers and Farming - A Study about Social, Economic and Ecological Factors Changing the Mountains Agriculture Scenario.

Investment Information and Credit Rating Agency(ICRA) Management Consulting Services Limited (2011). Skill Gap Study of the North East. National Skill Development Report.

https://nsdcindia.org/sites/default/files/files/as sam-sg.pdf

Kamei, P. (2019). Both geography and culture of Arunachal Pradesh makes it one of the most vibrant states in India.

https://www.outlookindia.com/outlooktraveller /explore/story/69301/visit-arunachal-pradeshfor-these-indigenous-festivals.

Keller, J.W. (2001). The Importance of Rural Development in the21st Century-Persistence, Sustainability \& Futures.

www.regional.org.au/au/countrytowns/.../kelle r.htm

Kerlin, JA. (2010). A comparative analysis of the global emergence of social enterprise. Voluntas: International Journal of Voluntary and Nonprofit Organizations, 21(2), 162-179.

Lodrick, D.O. (2019). Arunachal Pradesh.

Encyclopaedia Britannica.

https://www.britannica.com/place/ArunachalPradesh

Myers, N., Mittermeier, R., Mittermeier, C. et al. (2000). Biodiversity hotspots for conservation priorities. Nature, 403, 853-858.

https://doi.org/10.1038/35002501 
Myrdal, Gunnar (1968). Asian Drama, New Delhi, p. 1290.

Nayak, P.K. (2011). The dialectics of globalisation in Arunachal Pradesh. Economic and Political Weekly, 46 (26/27), 263-267. https://www.jstor.org/stable/23018648

Papola, T.S. (2008). Employment Challenge and Strategies in India An Assessment in the Framework of ILO's Global Employment Agenda. International Labour Organization

PricewaterhouseCoopers (PwC) International Ltd. (2014, November). Future of India - The Wining Leap.

https://www.pwc.in/assets/pdfs/future-ofindia/future-of-india-executive-summary.pdf

Putnam, R. (1993). Making Democracy Work: Civic Traditions in Modern Italy. Princeton University Press.

Putnam, Robert (2000). Bowling Alone: The Collapse and Revival of American Community. Simon \& Schuster.

Rajiv Gandhi University (2020). https://rgu.ac.in/

Sareen, R. (2017, 25 November ). Bamboo cycles made by Pune company may soon grace a cycle track near you. The Indian Express. https://indianexpress.com/article/india/bambo o-cycles-made-by-pune-company-may-soongrace-a-cycle-track-near-you-4953621/

Sharma, M., \& Chakraborty, D. K. (2016). Why Arunachal Pradesh's Social Sector Development is Asymmetrical: A Cross-district Investigation. Social Change, 46(2), 165-181. https://doi.org/10.1177/0049085716635389

Shira, D., \& Associates, Devonshire-Ellis, C. (2012). An Introduction to India. In: Shira, Dezan \& Associates, Devonshire-Ellis C. (eds). Doing Business in India. India Briefing (The Practical Application of India Business). pp. 17. Springer. https://doi.org/10.1007/978-3642-27618-7_1

Singh PJ (2018). Digital Industrialisation in Developing Countries: A Review of the Business and Policy Landscape. IT for Change, Delhi.
Skills Training for Advancement in Rural Societies (2020).

http://www.starsforum.org/affiliates/wpbdp_c ategory/skills-training/

The World Bank (1997). Executive Summary. In India; Achievements and Challenges in Reducing Poverty.

The World Bank (2020). The Global Economic Outlook During the COVID-19 Pandemic: A Changed World.

Varma, G.R \& Ravi, J. (2017). Social

Entrepreneurship: A Case Study on Amul Diary. International Journal of Research in Management Studies, A Peer Reviewed Open Access International Journal. 02(04), pp 23-32. https://fdocuments.in/document/socialentrprenurship-a-case-study-on-amul-23-socialentrprenurship-a-case-study.html

World Economic Forum (2019). The Travel and Tourism Competitiveness Report 2019: Travel and Tourism at a Tipping Point. Geneva. http://www3.weforum.org/docs/WEF_TTCR_20 19.pdf

\section{Conflict of Interest}

There are no conflicts of interest with respect to the research, authorship, and/or publication of this article

\section{Acknowledgements}

The authors would like to acknowledge contributions from all the primary and secondary sources whose data and writings have significantly benefitted the article in terms of formulating lines of argument and drawing inferences for SWOC Analysis. Authors are much grateful to the reviewers (blind reviews) for their quality input and insightful suggestions which have contributed immensely in enriching the article.

\section{Author Contribution Statement}

Dr Ravi Ranjan Kumar: Conceptualisation and designing the manuscript; writing the first draft; reviewing and re-writing the final draft, crosschecking for references.

Dr. Kaushalendra Pratap Singh (corresponding author):conceptualisation;collecting references; 
developing the first draft with the incorporation Ms. Leeyir Ete: Initial reviewing of the of new ideas and relevant resources; manuscript.

methodology; documenting the second draft;

and routine correspondence with the Editorial

Board of the journal. 